NBER WORKING PAPER SERIES

THE COMPLIANCE COST OF ITEMIZING DEOUCTIONS:

EVIDENCE FROM INDIVIDUAL TAX RETURNS

Mark M. Pitt

Joel Slemrod

Working Paper No. 2526

\author{
NATIONAL BUREAU OF ECONOMIC RESEARCH \\ 1050 Massachusetts Avenue \\ Cambridge, MA 02138 \\ March 1988
}

The research reported here is part of the NBER's research program in Taxation. Any. opinions expressed are those of the authors and not those of the National Bureau of Economic Research. 
NBER Working Paper \#2526

March 1988

\section{The Compliance Cost of Itemizing Deductions: Evidence from Individual Tax Returns}

\section{ABSTRACT}

The resource cost of operating the income tax system is large, totalling as much as seven to eight percent of revenue raised. One source of this cost is the system of itemized deductions, which can require extensive record keeping and calculation.

This paper estimates the resource cost of itemizing deductions. In contrast to previous studies of compliance cost which rely on survey evidence, we infer this evidence from data reported on tax returns which suggest that there exists taxpayers who would save mongy by itemizing but who choose not to.

We find that in 1982 the private coss of itemizing totalled $\$ 1.44$ billion, or $\$ 43$ per itemizing taxpayer. The compliance cost dissuaded from itemizing over 650,000 taxpayers who would have thereby saved taxes, causing an extra tax liability of nearly $\$ 200$ million. Increasing the standard deduction by $\$ 1,000$ would save $\$ 100$ million in resources that would otherwise have been devoted to itemizing.

Mark M. Pitt

Department of Economics University of Minnesota Minneapolis, MN 55455
Joel Slemrod

Department of Economics

The University of Michigan Ann Arbor. MI 48109 
The Compliance Cost of Iterizing Deductions:

Evidence from Indfuldual Tax Returns

1. Introduction

The resource cost of operating the income tax system is large. Although economists have traditlonally focused on the allocative effects of taxaton, Slemrod and Sorwa (1984) recenty estimated the direct cost of collecting individual income taxes 101982 to be between $\$ 30$ and $\$ 35$ blilion, or seven to eight percent of revenues raised. They found that the tide spent by taxpayers in complying wtth the tax law (approximately two billion hours, or twenty hours per cax year and one hundred millon taxpayers) is equivalent to a hidder bureaucracy of one aillion full-tfme ctvil servants. Approximately three-fourths of this cost was borne directly by taxpayers (as opposed to the Internal Revanue Service) in the process of record keeping, reseatching the tax law, and preparing the cax return itself. This high cost is widely perceived, as evidenced by the emphasis in the recent tax reform effort on simpliftcatton, which presumably ts related to reducting the resource cost of operating the syster. The Tax Reform Act of 1986 reduced marg1nal tax rates, 1ncreased the standard deduction, and eliminated some tcemized deductions, all of which arguably could reduce the cost of collection. However, the econometic analysis presented in Slemrod (1985) could find no support that reducing marginal tax rates would reduce complance cost. It did, though, suggest that reducing the fraction of taxpayers that itemize deductions would reduce compliance cost significantly.

This paper provides further evidence about the compliance cost of itemizing deductions and the determinants of the cost. In contrast to all previous studies which rely on survey evidence, we infer this evidence from data reported on tax returns, which of course contain no direct informatton on conpliance costs. We do, though, observe enough fnformation about itemizing and 
nonitemizing taxpayers to suggest that there exist taxpayers who would save Doney by itemizing but do not choose to. We postulate that they so choose because the compliance cost of itemizing exceeds the tax saving that can be obtalned. This allows us to estimate the magnitude and determinants of the cost of itemizing deductions. We find that in 1982 the private cost of itemizing totalled $\$ 1.44$ billion, or $\$ 43$ per itemizing taxpayer.

That legitimate reductions in tax liability are frequenty foregone by taxpayers has been recognized in the past. Perhaps the most striking example of this was documented by Steuerie, McHugh, and Sunley (1978), who Eound that only $31.3 \%$ of those eligible (and who therefore could have saved money) for income averaglng did so in 1971. Eligible non-electors on average passed up potential savings of $\$ 144$ (i971 dollars). They noted that the fraction of those eligible using income averaging increased substantially with adjusted gross income.

The phenomenon of non-participation in apparentiy rewarding government programs has been observed in other contexts. Moffitt (1983) noted that, in 1970, only $69 \%$ of families eligible for t. 1 to Families with dependent children participated in the program, while the food stamp participation rate was only $38 \%$. Moffitt modeled this behavior as resulting from "stigma" the disutility arising from participation in a welfare progran per se. However, he remarks in a footoote that

"Another possible explanation is that the costs of applying for the program and of complying with the rysiad program regulations make the benefit not woth the effort in obtaining and keeping it; that is, the transaction costs may be too high. This phenomenon is almost impossible to distinguish from stigma, so it is ignored here."

There is no stigma attached to itemizing one's deductions on a tax form. We conclude that it is the transactions cost of itemizing that causes some taxpayers who could pay less in taxes by itenizing to choose instead to us the standard deduction. 
Section 2 of the paper describes the empirical model that underlies the analysis. The data are descrlbed in section 3. The econometric results are presented in Section 4 , along with the estimates of the costs of compliance and tax saving foregone by not ltemizing for various groups of taxpayers. In addition, the model is used to predict the effect of alternative ainimum standard deduction levels. Section 5 offers some concluding remarks.

\section{The Empirical Model}

At the beginning of the tax year, taxpayers are assumed to know theis income, marginal tax rate, and other factors that influence the dollar amount of deductible activities that will be undertaken during the tax year. In addition, they know all factors that affect the "cost of itemizing." This cost may include actual and imputed compliance casts such as the value of time required to collate receipts and fill out forms ant the costs of purchased accounting services. In addition, the private cost of itemizing includes the psychic costs (or benefits) related to the compliance activity. The cost of itemizing for some ray include fear of complicating one's relationship with a powerful agency of the state--this cost may not be entrely psychic, as the probability of audit may depend on the itemization decision. On the other hand, one night obtain psychic satisfaction from reducing tax payments $[n$ excess of the resource costs of compliance at the margin. For example, it might be that a taxpayer values dollars pald to the state in a way that reflects his political or other judgments concerning its expenditure or other policies. Alternatively, one raight simply enjoy the activity of minfmizing tax payments.

The atternative to itenizing deductions is to take the standard deducton, which is a known amount depending only on marital and household status. The taxpayer will icemize only if the tax saving from ltemizing (TS f $_{1}$-defined as 
the cax bill it rhe minimu standard deduction is chosen less the cax bill if icerizing is chosen--exceeds the (privace) cost of complying with the requirerants of itemization. The cax savings from itemizing depends on the demand for deductible items by the ith taxpayet and the tax function. Tax savings, TS is rodeied as a inear function of a vector of observabie exogenous variabies ( $\left.x_{1}\right)$ which may affect both the demand for deductible lcems and the tax function condicional on this demand. Formally,

$$
T S_{i}=x_{i}^{3}+u_{i},
$$

where $u_{i}$ is an ertor cerm sumarizing all the unobservable influences on $T S_{i}$ including preference hecerogeneity, and 3 is a vector of unknown parameters.

The cost of compiance $\left(C_{i}\right)$ is similarly modeled as a linear function of a set of observabie exogenous regressors $\left(Z_{i}\right)$ and an error term $\left(v_{i}\right)$

$$
c_{i}=z_{i} \gamma+v_{i}
$$

The errors $u_{1}$ and $v_{i}$ are assumed to be discribuced as joint normal with zero means and covariance matrix

$$
\Sigma=\left|\begin{array}{ll}
\sigma_{u} & \sigma_{u v} \\
\sigma_{u v} & \sigma_{v}
\end{array}\right| .
$$

Taxpayers wil icemize only if $\mathrm{TS}_{1}>\mathrm{C}_{1}$. Define a dumy varlable $I_{1}$ such that

$$
\begin{aligned}
& I_{1}=1 \text { iff } T S_{i}>C_{1} \\
& I_{1}=0 \text { otherwise. }
\end{aligned}
$$

It is clear chat TS $S_{1}$ is only observed when $I_{1}=1$ and that $C_{t}$ is never observed. We do know if $\mathrm{TS}_{1}<C_{1}$ and can write the probability of this event as 
$(4) \quad \operatorname{Prob}(\mathrm{TS}<C)=\Phi\left(\frac{Z Y-X B}{\sigma}\right)$

where $p()$ is the standard normal cumulative function and $\sigma=\left(\sigma_{u}^{2}+\sigma_{v}^{2}-\right.$ $\left.20 v_{u}\right)^{\frac{1}{2}}$ is the standatd deviation of ( $\left.u-v\right)$. Defining $f(u, v)$ as the bivariate normal density of $u$ and $v$, then the likelthood function ts

$$
L(\beta, Y, Z)=\pi_{I=1}^{T S} \int_{-\infty}^{T S-X B} E(T S-X B, v) d v \prod_{I=0}^{\pi} \phi\left(\frac{Z Y-X \beta}{\sigma}\right)
$$

This model corresponds to the censored regression model with an unobserved stochastic censoring threshold considered by Gronau (1974), and Nelson (1977). Nelson demonstrated that identification requires that either $\sigma_{u v}=0$ or that at least one variable $i n x_{i}$ is not included in $Z_{i}$. The zero er cor covariance testriction, requiting that unobservables that influence tax savings are orthogonal to unobservables influencing compliance cost, does not have clear justification. Fortunately, a strong case can be made that not all variables in $X_{i}$. which influence tax savings also influence compliance cost. These cestrictions arise from the belief that compliance cost depends on the complexity of the temizacion process but not on the doliar value of the individual deductions: so that variables which affect dollar yalues and not complexity are sources of identifying restrictions. The actual identifying restrictions used are described below.

\section{Data}

The data used Eor this study are drawn Erom the 1982 Treasury Tax Etle. This is a stratfied randor sample of individual income tax recurns which heavily oversamples high income tax returus. Although the 1982 sample contains over 116,000 records, Eot computational economy we. work with a one-in-four sauple of the original Eile, totaling 29,407 tax records. The sample used in the 
estimacion concained only those cax recums for which adjusted gross income lay in the incerval $\$ 5,000$ to $\$ 100,000$ and which were not excluded for certain orher reasons described below. The sample used in the estimation cotalled 13,409 tax recurns.

There are four classes of taxpayers who were required to ltemize deductions even if these deductions sum to less than the standard deduction. Clearly the model described above does not apply to these taxpayers. These classes are (i) married taxpayers who Elle separate returns, (1i) individuals with earned income less than the standard deduction claimed as a dependent on their patents' return, (iil) rontesident alien individuals, and (lv) U.S. cititens who exclude incone from sources $1 n$ U.S. possessions. We deal with class (i) by eliminaring from the sample all married taxpayers filing separately, and deal with class (ii) by eliminating all single taxpayers with earned income less than the standard deduction. We do not have the information requited to identify taxpayers who are in categories (i1i) and (iv). We rely on the fact that chese situaEions are rare.

The dependent variable in the tax savings equation is scaled as $\ln$ (TS $_{i}+$ 1700). This form restricts predicted tax savings to be no less than minus $\$ 1,700$, which is the lowest possible potential tax saving, occurring when pocential icemized deductions are zero and the marginal cax race is 0.5 , the scatucory maximum. Hence chis functional form restricts potencially deductible expenses to be non-negartve. The unobserved dependent variable in the associfaced cost of itemizing equation becomes $\ln \left(C_{1}+1700\right)$, chus preserving the caxpayer's decision rule (equacion 3).

The explanatory varlables in $X_{1}$ and $z_{i}$ are described in Table 1 . The taxpayer characteristic variables (age szatus, marital scacus, number of personal 
In both $X_{1}$ and $Z_{i}$ :

$\begin{array}{ll}\text { Mar: } & =1 \text { if martied, } 0 \text { otherwise } \\ \text { AGI: } & \text { natural logarlthm of adjusted gross income } \\ \text { ACISQ: } & \text { squared natural logarithm of adjusted gross income } \\ \text { Business: } & =1 \text { if Earm or business Income, } 0 \text { otherwise } \\ \text { Aged: } & \text { number of aged exemptons taken } \\ \text { Exempt: } & \text { number of caxpayer exemptions }\end{array}$

In $x_{1}$ only (identifying):

Invinc: logarithm of positive lavestment income

Statetax: the average rate of state income and sales tax 1 n 1982 at $\$ 40,000$ ( 1979 dollars) of adjusted gross incone times aGI

Proptax: the average affective rate of property taxes in the taxpayer's state times AGI, 19822

Medcost: index of state medical costs ${ }^{3}$

Sources: 1. Tax tates taken from Feenberg and Rosen (1985), Table 4.2a, Column 13.

2. Tax rates taken from Advisory Commission on Intergovernuental Relacions (1985), p: 106.

3. Expense per day of care at commulty hospitals. Erotu Levit (1985), p. 23, Column 3. 
exemptions and business status) are assumed to potentially affect both the cost of compliance and the amount of itemizable dedictions. Adjusted gross income represents both its important effects on the tax function and income effects on the demand fot deductible ttems of expenditure. The identifying variables inciuce investment income and three indices of the "price" of deductible experses. We posit that various rates of taxation in a state and the prices of medical services affect the level of deductible expenses of otherwise identical taxpayers but do not affect the cost of compliance, which depends on the conplexity of the itemization process and not on the dollar value of the individual deductions. For example, the resource cost of deducting a $\$ 1,000$ hospital bili is equal to the resource cost of decucting a $\$ 2,000$ hospital bill for the sade set of hospital services. (Hospital services are particularly attractive in this regard, since it seems unlikely that the complexity of deductible expenses is responsive to this price.) Likewise, the complexity of deducting a property tax bill does not seem likely to depend on its magnitude. 1 Prices of certain itemizable deductions and tax rates affect only dollar waiues of deductions and not the complexity of itemizing them. Investment incone is also excluded from the cost of itemizing equation with similar teasoning. Investment income generates deductible interest expenses of greater value but not greater complexity than ordinary consumer creit. ${ }^{2}$

\section{Results}

The itemization decision model described by equations 1 and 2 was estimated by maximizing the likelihood given in expression (5). Parameter estimates and t-ratios are presented in Table $A-1$ in the Appendix. If compliance costs are identically zero for all taxpayers our stochastic censoring threshold model would collapse to a standard Tobit model. A likelihood ratio test strongiy 
rejects the hypochesis that compliance costs are identically zero $\left(x^{2}(9)=\right.$ 59.4). Furthermore, the cost of compliance is confirmed to vary. with caxpayer characteristics, since a test of the null hypothesis that the slope parameters of the estinaced scochastic cost of compliance equation are jointly zero ts also rejected $\left(x^{2}(6)=21.0\right)$. Similarly, the null hypothesis that tax saving does not vary wich caxpayer characteristics is also conclusively rejected $\left(x^{2}(10)=20309\right)$. Finally, a cest of the null hypothesis that the 1dentfeylng vartables in the cax savings equation are jolntly zero is rejected $\left(x^{2}(4)=\right.$ $750.2)$.

Because the parameter estimates are difficult to intorpret directly, Table 2 presencs the implied impact effects of each varfable, when evaluaced at the mean characceristics of each of three fincome classes. These are changes in the uncondicional expectacions of porential cax saving and the cost of icemizing.

Each of the stacewide indicacors of the "price" of 1temizable deductions has che expected positive sign in che cax savings equation. An increased price of hospical services, a higher level of scace income taxes, and a higher level of propercy caxes all are positively relaced to tax savings. Increasing the average race of scate income and sales tax by 0.01 (compared to a state average of .050) increases the potential cax saving from tlemization by $\$ 23$ for someone In che $\$ 10,000-\$ 15,000$ income range, by $\$ 54$ for someone to the $\$ 20,000-\$ 25,000$ range and by $\$ 158$ for someone in the $\$ 50,000 \$-75,000$ income range. Increasing the average effective property tax by .01 (compared to a state mean of .013) increases potential cax saving due to itemization by $\$ 33, \$ 78$, and $\$ 229$ for these three income classes. An increase of $\$ 100$ in hospical expense per day (wich a scate averge of $\$ 327$ ), increases pocencial saving by $\$ 115, \$ 205$, and $\$ 490$ for the three income classes. Over most of tis range, higher income is associaced with higher cax saving, as are more personal exemptions and the 
Tabie 2

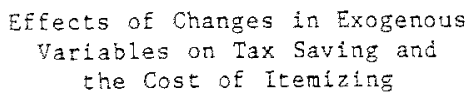

Iax Savings

AGT Class

$\$ 10,000-14,999$

$25,000-29,999$

$50,000-74,999$

$\triangle A G I=\$ 1,000$

38.67

60.78

99.72

$\Delta$ Invest $=\$ 1,000$

36.00

47.66

35.65

AExempt $=1$

52.09

92.97

221.74

Dbusiness $=1$

166.43

297.07

708.51

Mar $=1$

$-29.21$

$-52.14$

$-124.35$

$\operatorname{Agged}=1$

$-100.31$

$-179.05$

$-427.04$

statecax $=.01$

22.86

53.89

158.20

AProptax $=.01$

33.02

77.96

229.16

$\triangle$ Medcost $=\$ 100$

115.13

205.49

490.09

\section{Cost of Itemizing}

$\begin{array}{lccr}\Delta A G I=\$ 1,000 & 1.21 & 2.03 & 1.69 \\ \Delta \text { Exempt }=1 & 2.44 & 2.47 & 2.54 \\ \text { BBusiness }=1 & -10.97 & -11.11 & -11.45 \\ \Delta \text { Mar }=1 & -19.82 & -20.06 & -20.69 \\ \Delta \text { Aged }=1 & -8.53 & -8.64 & -8.91\end{array}$

Note: These are changes in the unconditional expectations of tax saving and the cost of itemizing. The $\triangle A G I$ calculations do not include the effect of changes in AGI on the variables Statetax or Proptax. The $\Delta$ Statetax and AProptax calcuiations refer to changes in the cax rates, holding AGI constant. 
presence of business or farm income. Being nat ied or having an aged exenption is each associated with lower tax savings, othe: factors being helf constant. The explanatory variables in the cost of itemizing equation were not as successful as in the tax saving equation. The presence of a farm or business reduces the cost of itemizing by about \$11; presumably because detailed records need to be kept even in the absence of itemizing, so that the incremertal cost is lower than otherwise. Increased income increases the cost of itemization. over most of its range (the cost of itenization is at a minimum at $\$ 9,568.05$ adjusced gross income), although a $\$ 1,000$ increase raises cost only by a dollat or two. The impact of personal and aged exemptions is not significantiy different from zero, although being married is associated with a significant decline in cost of about $\$ 20$.

The estimated private cost of itemizing deductions, by adjusted gzoss income class, is presented in Table $3 .^{3}$ These conditional expectarions were calculated by applying the mean vector of characteristics of itemizers within a class to the estimated equation of Table A-1. The average cost of itemizing for all itemizers is estimated to be 943.00 , which impites an aggregate coipliance cost of $\$ 1.44$ billion $1 \mathrm{n} 1982$.

Except for the lowest income class, the average cost of itemizing increases monotonically with incone. ${ }^{4}$ This reflects predominantly the positive direct effect of income on cost, where income undoubtedly proxies for the value placed on an individual's time.

Table 4 shows the tax savings that are foregone because some taxpayers are dissuaded from icerizing by the transaction cost. The first column indicates that there are 679,300 taxpayers who chose not to itemize given the curtent cost of itemizing (so that $\mathrm{TS}_{1}<\mathrm{C}_{i}$ ) but who would have itenized if the cost were zero $\left(\mathrm{TS}_{1}>0\right)$. The second columa of Table 4 shows that the Eoregone rax 
Table 3

Estimated Cost of Itemizing by Adjusted Gross Income Class, 1982

$\begin{array}{lccc}\begin{array}{c}\text { Adjusted gross } \\ \text { income class }\end{array} & \begin{array}{c}\text { Number of } \\ \text { itemizers } \\ \text { (thousands) }\end{array} & \begin{array}{c}\text { Average cost } \\ \text { of itemizing } \\ \text { for itemizers }(\$)^{2}\end{array} & \begin{array}{c}\text { Total cost of } \\ \text { itemizing for } \\ \text { itemizers (\$ milions) }\end{array} \\ \text { Less than } 5,000 & 690 & 23.95 & 16.52 \\ 5,000-9,999 & 1,700 & 15.77 & 26.81 \\ 10,000-14,999 & 2,745 & 12.26 & 33.66 \\ 15,000-19,999 & 3,219 & 16.33 & 52.57 \\ 20,000-24,999 & 4,228 & 25.08 & 106.02 \\ 25,000-29,999 & 4,706 & 33.02 & 155.40 \\ 30,000-39,999 & 7,657 & 45.01 & 344.63 \\ 40,000-49,999 & 4,217 & 62.10 & 261.89 \\ 50,000-74,999 & 2,871 & 86.43 & 248.15 \\ 75,000-99,999 & 677 & 126.89 & 85.90 \\ 100,000 \text { and } & 723 & 146.73 & 106.23 \\ \text { above } & & 43.00 & 1,437.78 \\ \text { Total } & 33,433 & 4 & \end{array}$

$a^{a}\left(C_{i} \mid I_{i}=1\right)=z_{i} \hat{\gamma}-\sigma_{u v}\left[\frac{\left.\phi_{i}\left(x_{i} \hat{B}-z_{i} \hat{\gamma}\right) / \sigma\right)}{\Phi\left(\left(x_{i} \hat{\beta}-z_{i} \hat{\gamma}\right) / \sigma\right)}\right]$ 
Table 4

Number of Addicional It amizers and

Tax Saving if Itemizing was Costless

Adjusted gross

income class

Less than 5,000

$5,000-9,999$

$10,000-14,999$

$15,000-19,999$

$20,000-24,999$

$25,000-29,999$

$30,000-39,999$

$40,000-49,999$

$50,000-74,999$

$75,000-99,999$

above
100,000 and

Additional itemizers

if cost of itemizing $=0$

(chousands)

38.7

60.5

50.4

74.1

108.7

115.8

153.3

54.8

12.8

0.2

0.1

Totat
1.36

\author{
Total tax \\ saving \\ (s millions)
}

1.90

1.53

12.43

$43.6:$

51.00

53.98

14.64

6.14

7.99

1.60

196.18 
saving of these taxpayers amounts to $\$ 196.2$ million. This is the revenue loss that the Treasury would suffer if the itenization process were costless. This highlights that the geretai goals of a tax system can conflict. In this case waking the tax system less costly to comply with conpromises the revenue collection objective of the tax system.

Einally, we calcuiate the impact of increasing the ruinimum standard deduction allowed for al1 taxpayers, as was legislated in the Tax Reform Act of 1986. This policy change has progressive implicatlons for vertical equity, as it eliminates all tax liability for many low-income households. Presunably ju also has a deleterious effect on horizontal equity, as it lints the applicability of a case-by-case standard for allowing deductions from taxable income. It also eliminates the tax incentive fot increased charitable contributions and other deductible activities for those taxpayers who no longer itemize. Our analysis allows us to measure another impact of increasing the standard deduction, the reduction in the aggregate cost of compliance. Table 5 shows how, as the standard deduction is increased, the number of itemizing households declines and the total cost of itemizing declines. An across-the-boat increase of $\$ 2,000$ in the standard deduction reduces the cost of compliance from $\$ 1.44$ to $\$ 1.07$ billion, or by $\$ 370$ million. Note also that the average cost of those households who remain itemizers increases. This occurs because the increased standard deduction reduces itemizing predominantly among lower income taxpayers, who on average have a lower private cost of itemizing. The Tax Reform Act of 1986 contains several changes which affect the extent of itemization, including the disallowance of the sales tax deduction, phaseout of the deduction for personal interest, and a floor on the deductability of miscellaneous expenses. It also substantially increased the standard deduction for each category of taxpayer, by less than $\$ 1,000$ for singles and 
Number of Iterizers and

Cost of Itemizing for Different Leve is of

the Standard Deduction

$\begin{array}{lc}1982 \text { level } & \begin{array}{c}\text { deduction } \\ \text { of standard } \\ \text { deduction }\end{array} \\ & \$ 1,000\end{array}$
Standard deduction incteased by $\$ 2,000$

Number of itemizers

(millions)

33.4

26.5

20.0

Total cost

of itemizing

( $\$$ billions)

1.44

1.26

1.07

Cost pet

i terizing

taxpayez (\$)

44.0

47.4

53.5 
more than $\$ 1,000$ for married couples filing jointly and single heads of households. Our estimates suggest that this latter provision will reduce the privace $\cos t$ of complying with the tax lat by approximately $\$ 0.18$ billion.

All of the foregoing estimates apply to che privately borne cost of itemization, as valued by the taxpayers. The social cost of compliance may, though, differ from the private cost. Most significanty, for monetary expendicures the social cost exceeds the privately-borne cost due to the deductibility of these expenses. The social cost of these expenditures is thus approximately $1 /(1-t)$ times the privately borne cost, where $t$ is the marginal rax rate.

\section{Conclusions}

The U.S. income tax syster allows caxpayers to deduct certain expenses from taxable incone in order co improve horizontal equity and to encourage certain activities, such as charitable giving, deemed socially desirable. This paper estimates that the privately borne cost in 1982 of allowing ltemizable deductions above some limit amounted to $\$ 1.44$ bilifon, with the social cost being sowethat higher. An increased scandard deduction, as legislated in the Tax Reform Act of 1986, enhances progressivity, diminishes the horizontal equity and incentive effects of icemization, but saves resource costs. We estimate that increasing all taxpayers" standard deduction by $\$ 1,000$ would save $\$ 180$ million in privately borne costs, and increasing it by $\$ 2,000$ would save $\$ 370$ million.

Earliet studies of the compliance cost of taxation have been based on survey responses, and therefore are subject to error due to faulcy memory or deiberate mistepresentation. How to value taxpayers' time spent on tax matters is also a difficulc problem in such studies. In addicion, only tangible resource costs of compliance can be measured with any accuracy. This paper 
proposes a nechodology to infer the cost of com liance fom caxpayers observed behavior. Thus $1 \mathrm{t}$ is not biased by survey resp nse inaccuracy and capcures psychic costs as we 11 as the caxpayer's valuacion of time and ocher resources used in cax compliance. These advantages make it a promising mechodology for estimating the complince cost of other regulatory requtrements. 


\section{Footnotes}

1. The existence of a state income tax is likely to complicate the itemization procedure. Adding a dumy variable for the presence of a state income tax in the cost of compliance equation was unsuccessful--the likelihood would not converge. Of the 13,409 records, only 80 were from states without an income tax, so that this influence is unlikely to be qualitatively important,

2. If investment income is included as an explanatory variable of cost of compliance, it is not statistically significant at common levels of significance.

3. The results reported here and in Table 4 for the lowest and highest adjusted gross income classes were obtained by applying the mean characteristics of the adjacent income class except in the case of income, in which case $\$ 5,000$ was used for the less than $\$ 5,000$ class and $\$ 100,000$ was used for the over $\$ 100,000$ class.

4. The nommonotonicity probably reflects the fact that taxpayers with low reported adjusted gross income are often not "poor, "but have temporarily low annual income or have taken tax losses that reduce their income subject to tax. 


\section{APPENDIX}

Table A-1

Maximum Likelihood Estimates of the Itemization Decision Model

Tax Savtigs Equation:

\section{Intercept}

AGI

AGISQ $\left(x .10^{2}\right)$

Exempt $\left(x 10^{2}\right)$

Business $\left(x 10^{2}\right)$

Mar $\left(x 10^{2}\right)$

Aged $\left(x 10^{2}\right)$

Medcost $\left(x 10^{2}\right)$

Invine $\left(x 10^{2}\right)$

Statetax $\left(x 10^{2}\right)$

Proptax $\left(x 10^{2}\right)$

$a_{u}$

\section{Parameter}

9.346

$-0.882$

25.892

4.571

13.928

$-2.658$

$-9.439$

9.837

1.073

1.161

0.807

0.474
As ymptocic

t-ratio

85.21

$-13.73$

21.52

12.01

14.06

$-1.92$

$-9.30$

15.20

6.36

17.97

3.42

148.83

Cost of Itemizing Equation:

Intercept

AGI

AGISQ $\left(x 10^{2}\right)$

Exempt $\left(x 10^{2}\right)$

Business $\left(x 10^{2}\right)$

Mar $\left(x 10^{2}\right)$

Aged $\left(\times 10^{2}\right)$

$\sigma_{v}$

$\sigma_{11 \mathrm{~V}}$

Log Likelihood

No. of Observations
7.527

$-0.069$

1.530

0.142

$-0.643$

$-1.165$

$-0.500$

0.013

0.0003

$-919.69$

13409

Variables are defined and scaled as follows:

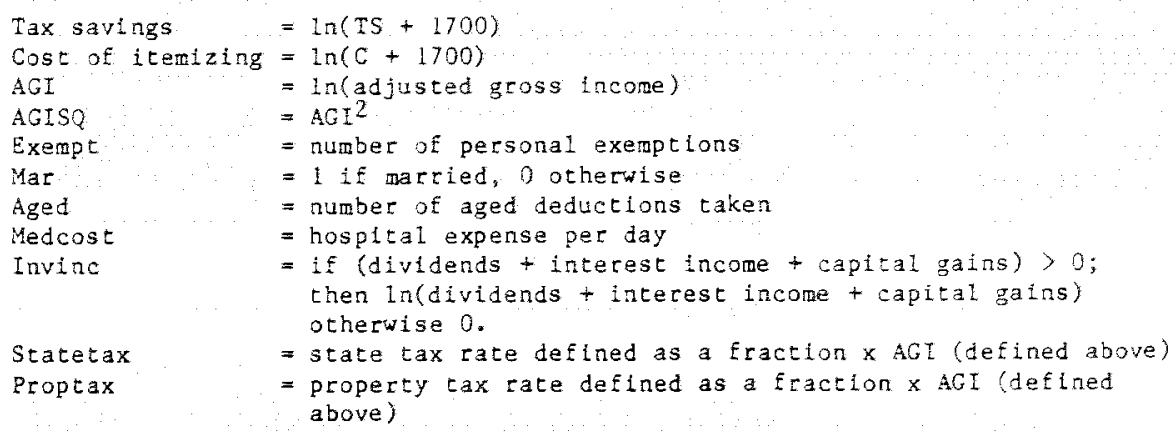

= property tax rate defined as a fraction $x$ AGI (defined above) 


\section{References}

Advisory Commission on Intergovernmental Relations, Significant Features of Eiscal Eederalism: 1984 Edition, Washington, D.C.: March 1985.

Feenberg, Daniel ․․ and Harvey Rosen, "State Personal Income and Sales Taxes: 1977-1983," National Bureau of Economic Research Working Paper No. 1631, June, 1985.

Gronau, Reuben, "The Effect of Children on the Housewife"s Value of Time," Journal of Political Economy Voi. S8! (March 1973).

Levit, Katharine, R., "Personal Health Care Expenditures, by State: 1966-1982," Health Care Financing Review Vol. 6 , No. 4 (Summer 1985).

Moffitt, Robert, "An Econoric Model of Welfare Stigma," American Econoric Review Vol. 73, No. 5 (December 1983).

Nelson, Forrest, "Censored Regression Models with Unobserved Stochastic Censoring Thresholds," Journal of Econometrics Vol. 6, No. 2 (April 1977).

Slemrod, Joel, "The Return to Tax Simpiffication: An Econometric Analysis," National Bureau of Economic Research Working Paper No. 1756, November 1985.

Slerrod, Joel and Nikki Sorum, "The Compliance Cost of the U.S. Individual. Income Tax Syster," National Tax Journal Vo1. 37, No. 4 (December 1984).

Steuerle, Eugene, Richard McHugh, and Emil M. Sunley, "Who Benefits from Income Averaging?" National Tax Journal Vo1. 31, No. 1 (March 1978). 